\title{
Potential of anthracite, dolomite, limestone and pozzolan as reactive media for de-icing salt removal from road runoff
}

\author{
A. de Santiago-Martín ${ }^{1}$ A. Michaux ${ }^{1}$ - G. Guesdon ${ }^{1}$ - B. Constantin ${ }^{1}$ \\ M. Despréaux ${ }^{2} \cdot$ R. Galvez-Cloutier ${ }^{1}$
}

Received: 24 March 2016/Revised: 8 June 2016/Accepted: 16 August 2016/Published online: 24 August 2016

(C) Islamic Azad University (IAU) 2016

\begin{abstract}
De-icing salt $(\mathrm{NaCl})$ application is a common practice during winter road maintenance in northern countries, compromising ecosystem services. Ecoengineering facilities, including reactive filter beds, are becoming an effective strategy for road runoff management. Different materials (anthracite coal, dolomite, limestone, and pozzolan) were tested as reactive media of filter beds. Characterization showed that dolomite has the best physical properties (resistance to fragmentation, porosity) for filter bed construction and maintenance, followed by limestone. $\mathrm{NaCl}$ removal efficiency was investigated in batch at different concentrations $\left(150-5000 \mathrm{mg} \mathrm{L}^{-1} \mathrm{Cl}\right)$. Removal efficiency substantially varied depending on the element $(\mathrm{Cl}$ or $\mathrm{Na})$, the material, and the added $\mathrm{NaCl}$ concentration. At the lowest $\mathrm{NaCl}$ concentration, $\mathrm{Cl}$ removal was higher onto anthracite $(48 \%)$ and dolomite (59\%); but greater Na removal was reached onto limestone $(54 \%)$ and pozzolan $(67 \%)$. At higher concentrations, $\mathrm{Cl}$ removal was similar (anthracite), decreased (dolomite), or increased (limestone, pozzolan); and $\mathrm{Na}$ removal increased (anthracite) or decreased (dolomite, limestone, pozzolan). Parallel experiments at $4{ }^{\circ} \mathrm{C}$ showed lower $\mathrm{NaCl}$ removal, anthracite being the most efficient. Practical applicability was evaluated in columns using synthetic runoff solution $(\mathrm{NaCl}$ and metals). $\mathrm{NaCl}$ removal
\end{abstract}

Editorial responsibiility: H. Pant.

A. de Santiago-Martín

ana.de-santiago-martin.1@ulaval.ca

1 Department of Civil Engineering and Water Engineering, Laval University, Quebec, Canada

2 Vinci Autoroutes - Autoroute du Sud de la France, Direction Technique de l'Infrastructure, Paris, France efficiency was much lower in column assays with respect to batch. The highest $\mathrm{NaCl}$ removal was reached onto dolomite, followed by limestone. Metals were successfully removed, generally remaining over time in a wide range $(41-89 \% \mathrm{Cd}, 78-97 \% \mathrm{Ni}, 44-88 \% \mathrm{Cu}$, and 3-83\% Zn) depending on the material, being pozzolan the least efficient. Further studies including a combination of materials would be of high interest.

Keywords Adsorption · Filter beds · Geomaterials . Highway pollution $\cdot \mathrm{NaCl} \cdot$ Surface water $\cdot$ Trace metals

\section{Introduction}

Anthropogenic salinity is a global and growing threat causing severe biodiversity losses and compromising the ecosystem goods and services provided by freshwater and soil. The application of de-icing salts, primarily $\mathrm{NaCl}$, has become a common practice in northern countries in order to carry out winter road maintenance. Most of the salts are transported by projection and splash, nebulization, wind transport, and/or runoff during rainfall events and snow melting periods (Blomqvist 2001), affecting: surface water (density, electrical conductivity), groundwater (polluting potential drinking water sources), soil (aggregate stability, organic matter dispersion, infiltration), and biodiversity (Green et al. 2008; Dai et al. 2012). There is also the additional risk of increasing the mobility of other pollutants found in roadside soils, such as trace metals primarily by the formation of chlorocomplexes (Bäckström et al. 2004; Rasa et al. 2006).

Ecoengineering facilities are becoming a widespread practice for road runoff pollution management. These facilities employ and amplify natural processes for 
removing pollutants (de-icing salts, trace metals, hydrocarbons) through a treatment chain consisting of several units including constructed wetlands $(\mathrm{CW})$, detention basins (DB), and underground reactive filter beds (FB). They have proved to be techno-economically feasible, energy efficient, and environmentally sensitive (Jiang et al. 2014). Nonetheless, while most of the studies on road runoff treatment are aimed at removing metals and polycyclic aromatic hydrocarbons (PAH) (Tromp et al. 2012), those targeted to the removal of de-icing salts are remarkably scarce (Rémi et al. 2013). In Quebec, a treatment chain consisting of a free water surface-flow $\mathrm{CW}$ (multiculture planting) in parallel to an underground reactive FB ( $80 \%$ limestone, $20 \%$ dolomite), and preceded by a DB, was constructed with the aim of treating de-icing salted runoff from A40 Highway (Morteau et al. 2008; Guesdon et al. 2013; Galvez-Cloutier et al. 2014). The authors showed that: (1) the global system successfully removed high $\mathrm{NaCl}$ amounts from collected road runoff; (2) $\mathrm{NaCl}$ was successfully removed by the $\mathrm{CW}$ during summer season, while removal rates decrease after storm events; and (3) $\mathrm{NaCl}$ was efficiently removed by the $\mathrm{FB}$ during and after medium and high precipitations. Hence, results proved the seasonal improvement of using FB as a first or second line to $\mathrm{CW}$ for de-icing salted runoff entering the treatment chain.

Reactive media of FB include material(s) ideally fulfilling one or more of the following characteristics: natural, unmodified, locally available, economic (low cost), physicochemically stable, resistant to fragmentation and dissolution, and efficient for removing a wide range of salts often present in road runoff (primarily de-icers and metals) (Morteau et al. 2008; Barral et al. 2014). Different materials have been proposed (alone or in combination) to remove from road runoff: PAHs and trace metals including gravel, sand, zeolite, vermiculite, granular activated carbon, and peat (Fuerhacker et al. 2011); and de-icing salts including limestone and dolomite (Galvez-Cloutier et al. 2014). Given the limited number of studies aiming at deicing salt removal, sorption experiments comparing different candidate materials are required. Among coals, anthracite is interesting for its abundance and microporous structure (Kim et al. 2003). It is a hard and compact material with lesser impurities than other similar mineral coals and has recently showed high removal efficiency of pollutants such as nitrobenzene and its derivatives (Parham and Saeed 2013). Carbonate rocks such as dolomite and limestone have been reported as effective candidate materials for removing a wide range of pollutants (both cations and anions): trace metals (Albadarin et al. 2012; Sdiri et al. 2012), iron (Aziz et al. 2004), phosphorus (Karaca et al. 2004; Mateus et al. 2012) and sulphate (Silva et al. 2012). Natural pozzolan is a black or red igneous rock whose porosity and cellular texture confers a high potential retention capacity. Pozzolan has been traditionally employed as building material (in cement and concrete), but it has revealed high suitability for removing $\mathrm{Cl}$ ions (Al-Rawajfeh et al. 2013) and chlorinated benzenes (Cottin and Merlin 2010).

The aim of this study was to comparatively analyse the $\mathrm{NaCl}$ removal capacity of four candidate materials (anthracite coal, dolomite, limestone, and pozzolan). The sorption of $\mathrm{Cl}$ and $\mathrm{Na}$ onto materials from aqueous solution was investigated in batch experiments. Some experiments were also carried out at $4{ }^{\circ} \mathrm{C}$. The practical applicability was experimentally tested under dynamic conditions in columns using a synthetic runoff solution including $\mathrm{NaCl}$ and trace metals $(\mathrm{Cd}, \mathrm{Cu}, \mathrm{Ni}$, and $\mathrm{Zn})$. The potential displacement of trace metals by $\mathrm{NaCl}$ was specifically discussed.

This research is part of a larger project conducted from 2011 to 2014. The selection and characterization of materials were performed from autumn 2012 to summer 2013 at Laval University (Canada), in collaboration with Autoroute du Sud de la France Company (France). The sorption experiments, in batch and columns, were conducted between autumn 2013 and summer 2014 on laboratory scale at Laval University.

\section{Materials and methods}

\section{Materials tested}

The reactive media we tested (hereafter referred as materials) were chosen based on five criteria: (1) potentially efficiency for removing $\mathrm{NaCl}$ and trace metals, (2) availability for sale, (3) economic (low cost), (4) physicochemically stable with a minor impact on ecosystems, and (5) natural and unmodified. Materials were supplied by Autoroute du Sud de la France Company and included: anthracite coal (Baldoyra coal, Eastern Pyrenees, France), dolomite (SRC, Gard, France), limestone (SMW Delorme, Orgon, Bouches-du-Rhône, France), and pozzolan (Ardechoise quarry, Ardèche, France) (Fig. 1). Materials ( $\sim 20 \mathrm{~kg}$ each, $20-50 \mathrm{~mm}$ ) were washed in abundant tap water to remove fine particles after which they were airdried ( 7 days) in all cases, and further oven-dried $\left(105^{\circ} \mathrm{C}\right.$, $24 \mathrm{~h}$ ) in the case of pozzolan. Then, each material was well homogenized and characterized (resistance to fragmentation, porosity, surface area, point of zero salt effect, and cation and anion exchange capacity), and sorption experiments in batch and columns were performed. Mineralogical composition of materials has been previously described (Guesdon and Galvez 2012). Briefly, materials showed a high purity: anthracite coal $\left(95 \% \mathrm{C}_{240} \mathrm{H}_{90} \mathrm{O}_{4} \mathrm{NS} ; 5 \%\right.$ 
Fig. 1 Materials tested as reactive media: anthracite coal (a), pozzolan (b), dolomite (c), and limestone (d)
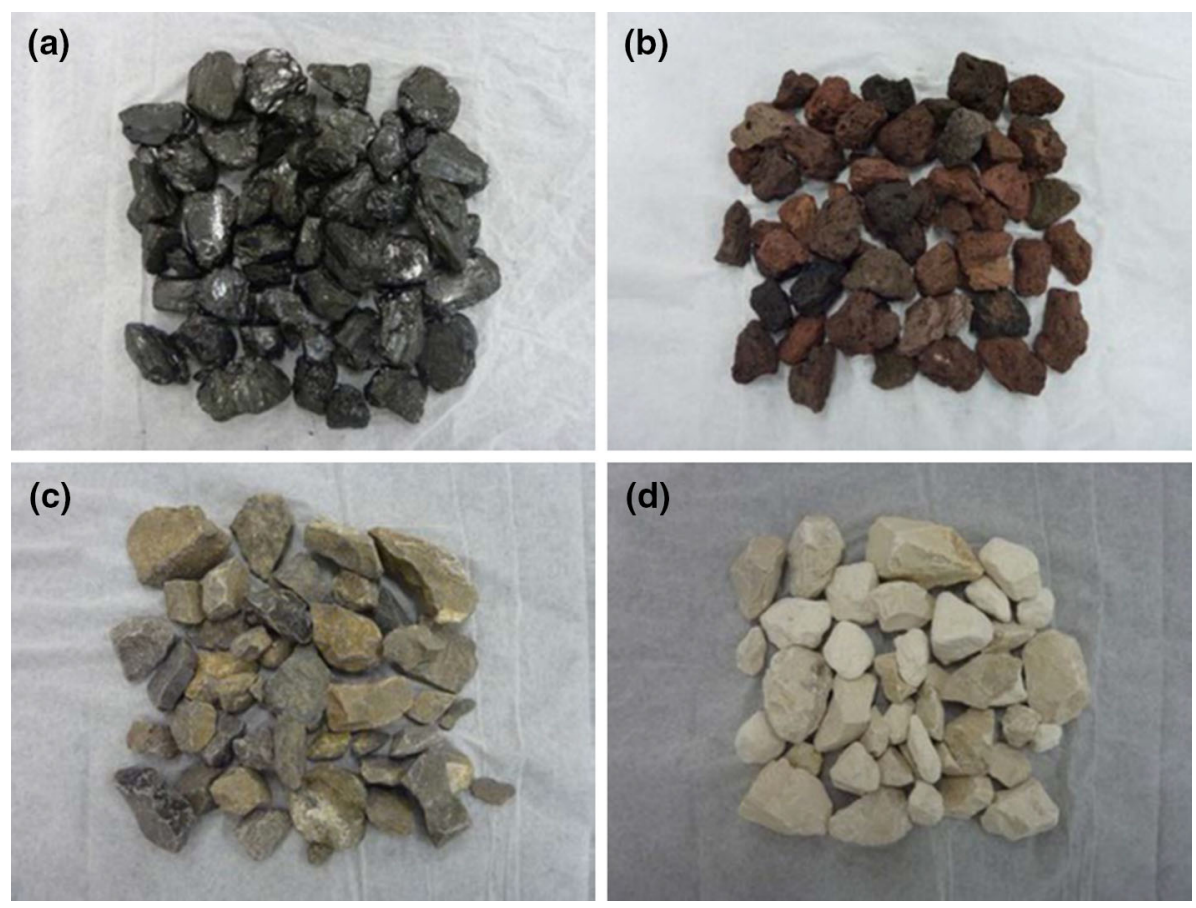

ankerite $\left.\mathrm{Ca}(\mathrm{Fe}, \mathrm{Mg}, \mathrm{Mn})\left(\mathrm{CO}_{3}\right)_{2}\right)$, dolomite $(98 \%$ $\left.\mathrm{CaMg}\left(\mathrm{CO}_{3}\right)_{2}\right)$, and limestone $\left(100 \% \mathrm{CaCO}_{3}\right)$. In the case of pozzolan, $44 \%$ augite, $(\mathrm{Ca}, \mathrm{Na})(\mathrm{Mg}, \mathrm{Fe}, \mathrm{Al}, \mathrm{Ti})(\mathrm{Si}$, $\mathrm{Al})_{2} \mathrm{O}_{6}, 20 \%$ olivine, $(\mathrm{Mg}, \mathrm{Fe})_{2} \mathrm{SiO}_{4}, 19 \%$ nepheline, $(\mathrm{Na}$, K) $\mathrm{AlSiO}_{4}$, and $9 \%$ anorthite, $(\mathrm{Ca}, \mathrm{Na})\left(\mathrm{Al}, \mathrm{Si}_{2}\right)_{2} \mathrm{Si}_{2} \mathrm{O}_{8}$, were predominant.

\section{Sorption experiments}

The use of fine particle size often generates big issues of hydraulic obstruction and clogging (Vohla et al. 2011). Hence, to simulate more realistic conditions extrapolated to full-scale FB systems, a 20-50-mm particle size was used for sorption experiments.

\section{Sorption curves: batch assays}

Isotherm assays were carried out in batch with $\mathrm{NaCl}$ as sorbate and the four materials (anthracite coal, dolomite, limestone, and pozzolan) as sorbents. All of the experiments were carried out in duplicate. Each material (200 g) was placed in $1000 \mathrm{~mL}$-polypropylene bottles with $500 \mathrm{~mL}(1: 2.5 \mathrm{w} / \mathrm{v})$ of $\mathrm{NaCl}$ aqueous solution containing 0 (control), $150\left(\mathrm{C}_{1}\right), 1500\left(\mathrm{C}_{2}\right), 3000\left(\mathrm{C}_{3}\right)$, or $5000\left(\mathrm{C}_{4}\right)$ $\mathrm{mg} \mathrm{L}^{-1}$ of $\mathrm{Cl}$. The bottles were shaken in a Mid-Range Reciprocal Shaker for $4 \mathrm{~h}$ (Eberbach Shaker) at $260 \pm 13$ oscillations per minute (opm) at a temperature of $22{ }^{\circ} \mathrm{C}$, according to previous studies (Galvez-Cloutier and Michaux 2013). Supplementary isotherm assays were performed in a cold chamber at a constant temperature of $4{ }^{\circ} \mathrm{C}$ with anthracite coal and dolomite, considering their greater potential based on the results at $22{ }^{\circ} \mathrm{C}$ and the characterization assays. Both the materials and the solutions were placed in the cold chamber $24 \mathrm{~h}$ before the experiment. At the end of the mixing period, the solutions were filtered under vacuum $(0.45-\mu \mathrm{m}$-pore-size cellulose ester membrane filter, Advantec Inc.). The filtrate was: (1) frozen for $\mathrm{Cl}$ quantification; or (2) acidified to $\mathrm{pH} 2$ by adding the necessary volume of concentrated $\mathrm{HNO}_{3}$ and kept at $4{ }^{\circ} \mathrm{C}$ for $\mathrm{Na}$ quantification.

Removal efficiencies (\%) were calculated by the following Eq. 1:

Removal $=\left(\frac{C_{\mathrm{i}}-C_{\mathrm{e}}}{C_{\mathrm{i}}}\right) \times 100$

where $C_{\mathrm{i}}$ and $C_{\mathrm{e}}$ are the initial (before removal) and equilibrium (after removal) $\mathrm{Cl}$ or $\mathrm{Na}$ concentrations in solution $\left(\mathrm{mg} \mathrm{L}^{-1}\right)$, respectively.

Sorbed $\mathrm{Cl}$ and $\mathrm{Na}$ concentrations $\left(q_{\mathrm{e}} ; \mathrm{mg} \mathrm{g}^{-1}\right)$ were calculated by the following mass balance relationship (Eq. 2):

$q_{\mathrm{e}}=V \frac{C_{\mathrm{i}}-C_{\mathrm{e}}}{W}$

where $C_{\mathrm{i}}$ and $C_{\mathrm{e}}$ are the initial and equilibrium $\mathrm{Cl}$ or $\mathrm{Na}$ concentrations in solution $\left(\mathrm{mg} \mathrm{L}^{-1}\right)$, respectively, $V$ is the volume of the solution $(\mathrm{L})$, and $W$ is the mass $(\mathrm{g})$ of the material. The equilibrium sorption data were fitted into the isotherm models of Langmuir (Eqs. 3 and 4) and Freundlich (Eq. 5), represented, respectively, by the following equations: 
$\frac{q_{\mathrm{e}}}{q_{\mathrm{e}}^{0}}=\frac{K_{\mathrm{L}}}{1+K_{\mathrm{L}} C_{\mathrm{e}}}$

$R_{\mathrm{L}}=\frac{1}{1+\left(1+K_{\mathrm{L}} q_{\mathrm{e}}^{0}\right)}$

$q_{\mathrm{e}}=K_{\mathrm{F}} C_{\mathrm{e}}^{\frac{1}{n}}$

where $K_{\mathrm{L}}$ and $K_{\mathrm{F}}$ are constants that depend on the type of material and the chemical species; $q_{\mathrm{e}}^{0}$ is the maximum sorption capacity $\left(\mathrm{mg} \mathrm{g}^{-1}\right)$ of the solid in the Langmuir model (Barral et al. 2014); $1 / n$ is a heterogeneity parameter in function of the strength of the sorption process.

Nonlinear regression was performed using a trial and error method with the help of solver add-in functions of Microsoft Excel software. In the trial error procedure, isotherm parameters were determined by maximizing the values of the coefficient of determination (Karadag et al. 2007).

\section{Multipollution scenario: column assays}

Duplicate transparent vertical Plexiglas columns $(12 \mathrm{~cm}$ internal diameter; $32 \mathrm{~cm}$ long) were packed with each of the four materials to a height of $12.5 \mathrm{~cm}$. In order to simulate the filling process that would occur in a FB in the field, the materials were released from the top of the column at one time until reaching $12.5 \mathrm{~cm}$ height. Vertical columns were fed upwards from their base with synthetic runoff solution at a $4.5 \mathrm{~mL} \mathrm{~min}^{-1}$ continuous up-flow maintained by a peristaltic pump (Model. 7553-80, ColeParmer Instrument Company, IL, USA) in closed atmosphere. The flow rate of $4.5 \mathrm{~mL} \mathrm{~min}^{-1}$ allowed a retention time of about $2.5 \mathrm{~h}$ (Galvez-Cloutier and Michaux 2013), in line with the 2-h minimum retention time recommended for FBs (Morteau et al. 2008). The synthetic solution included $\mathrm{NaCl}$ at $150 \mathrm{mg} \mathrm{Cl} \mathrm{L}^{-1}\left(\mathrm{C}_{1}\right.$ level) and a mixture of trace metals $(\mathrm{Cd}, \mathrm{Cu}, \mathrm{Ni}$, and $\mathrm{Zn})$. Metals were added using chloride $\left(\mathrm{CdCl}_{2}\right)$ or sulphate salts $\left(\mathrm{CuSO}_{4} \cdot 5 \mathrm{H}_{2} \mathrm{O}\right.$, $\left.\mathrm{NiSO}_{4} \cdot 6 \mathrm{H}_{2} \mathrm{O}, \mathrm{ZnSO}_{4} \cdot 7 \mathrm{H}_{2} \mathrm{O}\right)$ in aqueous solution at $2 \mathrm{Cd}$, $20 \mathrm{Cu}, 3 \mathrm{Ni}$, and $300 \mathrm{Zn} \mu \mathrm{g} \mathrm{L}^{-1}$ in order to simulate a multipollution scenario as typically reported in road runoff (Wong et al. 2000; Galvez-Cloutier and Michaux 2013). At different time intervals $(0,15,30,60,90,120,180,240$, $360 \mathrm{~min}, 1,2,3,5,7,10$, and 20 days), $50 \mathrm{~mL}$ of both the input (reservoir) and the output solutions (top of the column) was recovered. The collected solutions were filtered under vacuum (0.45- $\mu$ m-pore-size filter, Swinnex 25, Millipore Inc.) and treated for storing until analysis as described above. For each time, $\mathrm{pH}$ values and concentrations of $\mathrm{Na}$, trace metals $(\mathrm{Cd}, \mathrm{Cu}, \mathrm{Ni}$, and $\mathrm{Zn})$, and major anions $\left(\mathrm{Cl}^{-}, \mathrm{HCO}_{3}{ }^{-}, \mathrm{CO}_{3}{ }^{2-}, \mathrm{NO}_{2}{ }^{-}, \mathrm{NO}_{3}{ }^{-}, \mathrm{PO}_{4}{ }^{3-}\right.$, and $\mathrm{SO}_{4}{ }^{2-}$ ) were measured. Visual Minteq v.3.0 computer program (Gustafsson 2011) was used to predict chemical speciation in the solutions. The database that comes by default in the Visual Minteq program was used. The $\mathrm{pH}$ values and concentrations $\left(\mathrm{mg} \mathrm{L}^{-1}\right)$ of $\mathrm{Na}$, trace metals, and major anions were used as input data, simultaneously entered into the code for each individual solution.

\section{Analytical methods}

Resistance to material fragmentation at two particle sizes (6.3-10 and 10-14 mm) was determined following the norm NF P 18-574 (AFNOR 1990), and dynamic fragmentation coefficient (DF) was calculated. Porosity was measured by gas pycnometry: envelope and skeletal volumes were obtained by means of a powder and helium pycnometers, respectively (Quantachrome Inc.). Surface area was determined by the methylene blue method (Santamarina et al. 2002). Bulk density was measured by dipping $M \mathrm{~g}$ of material in a known volume of water $(V \mathrm{ml})$ and was expressed as the $M$-to-final $V$ ratio. Materials were ground (Fritsch Pulverisette) and passed through a 400- $\mu \mathrm{m}$ sieve. Then, point of zero salt effect test (PZSE) and cation (CEC) and anion exchange (AEC) capacities were determined by long equilibrium time method and $0.5 \mathrm{~mol} \mathrm{~L} \mathrm{~L}^{-1}$ ammonium nitrate methods, respectively (Pansu and Gautheyrou 2006).

In the solutions collected from batch and column assays, concentration of anions $\left(\mathrm{Cl}^{-}, \mathrm{HCO}_{3}{ }^{-}, \mathrm{CO}_{3}{ }^{2-}, \mathrm{NO}_{2}{ }^{-}\right.$, $\mathrm{NO}_{3}{ }^{-}, \mathrm{PO}_{4}{ }^{3-}$, and $\mathrm{SO}_{4}{ }^{2-}$ ) was quantified by high-performance liquid chromatography-HPLC (1525 Binary HPLC Pump System, Waters Inc.); Na by flame emission atomic spectroscopy-EAS; Zn by flame absorption atomic spectroscopy-AAS (AA240FS, Varian Inc.); and $\mathrm{Cd}, \mathrm{Cu}$, and $\mathrm{Ni}$ by graphite furnace AAS with Zeeman background correction (AA240Z, Varian Inc.). Detection limit in $\mu \mathrm{g} \mathrm{L}^{-1}$ was: $\mathrm{Cd}=0.01, \mathrm{~Pb}=0.2, \mathrm{Na}=2, \mathrm{Ni}=0.24$, $\mathrm{Zn}=10, \mathrm{Cl}=25, \mathrm{HCO}_{3}=50, \mathrm{CO}_{3}=50, \mathrm{NO}_{2}=50$, $\mathrm{NO}_{3}=75, \mathrm{SO}_{4}=75, \mathrm{PO}_{4}=125$. All chemicals and reagents were analytic grade from Fisher Scientific Inc. (Canada) and EMD Chemicals Inc. (USA). All glassware used was rinsed with nanopure water (Ultrapure Water System, Barnstead Nanopure).

\section{Statistical analyses}

Significance of differences of $\mathrm{Cl}$ and $\mathrm{Na}$ removal efficiency by materials among $\mathrm{NaCl}$ levels $\left(\mathrm{C}_{1}, \mathrm{C}_{2}, \mathrm{C}_{3}\right.$, and $\left.\mathrm{C}_{4}\right)$ was investigated by means of one-way analysis of variance (ANOVA) using a post hoc test (Tukey). Before performing the ANOVA test, a Levene's test was performed to analyse the homogeneity of variance. These analyses were made using the Statistical Package for the Social Sciences v.17 (SPSS Inc.) software. Graphics were created using GraphPad Prism v. 6.01 software (GraphPad Inc.). 


\section{Results and discussion}

\section{Characterization of materials}

Ensuring the resistance of materials is essential to maximize its effectiveness during underground reactive FB construction and maintenance (transport, installation, compaction, and replacement of materials). Resistance of materials to fragmentation gives an idea of its sensitivity to changes in its particle size, which could lead to clogging and then losses in filtering properties. In this regard, dynamic fragmentation coefficient (DF) is a good indicator of the material sensitivity to a mechanical impact, the lower DF the greater resistance to fragmentation. As shown in Table 1, similar DFs were obtained for dolomite, limestone and pozzolan $(\sim 28 \%)$. Anthracite coal showed the highest DF (about twice) which evidences its lower fragmentation resistance. Higher material porosity provides greater hydraulic conductivity but also determines the amount of water that can be retained by materials. Hence, increased porosity may enhance fragmentation in the medium and long term during hot-cold, wet-dry and freeze-thaw cycles. Pozzolan showed the largest porosity $(57 \%)$, consistent to previously reported (Cottin and Merlin 2010), followed by limestone (22\%), and ultimately by dolomite (4\%). So it can be inferred that dolomite presents the best physical properties for minimizing fragmentation processes, followed by limestone. Anthracite coal porosity could not be measured, but it is expected to be quite high, $\sim 50 \%$ (Wang et al. 2009).

Porosity was positively related to the surface area and negatively to bulk density (Table 1), as often observed (Prochaska and Zouboulis 2006). Hence, anthracite coal showed the highest surface area, according to literature (Jiang et al. 2014), followed by pozzolan, suggesting a greater sorption capacity. Surface area values per unit of mass of material were lower than those obtained by other authors (Toprak and Kopac 2011). Most studies employ a particle size far below, between 0.02 and $10 \mathrm{~mm}$ (Vohla et al. 2011). The low surface area of materials in the present study is consistent with the selected larger particle size
(20-50 mm). This may involve that some of the interior pores could be unapproachable by the $\mathrm{Cl}$ and $\mathrm{Na}$ ions (Albadarin et al. 2012) and thus lower removal efficiency than in other studies is expected. Surface area and porosity were positively related to cation exchange capacity (CEC). CEC determines ion sorption ability by complexation, ion exchange, and precipitation (Bradl 2004). The highest CEC was measured in pozzolan, followed by anthracite coal; being five and three times more, respectively, than the lowest (dolomite). Anion exchange capacity (AEC) was very low for anthracite coal and lower than the quantification limit $\left(0.05 \mathrm{cmol}_{-} \mathrm{kg}^{-1}\right)$ for dolomite, limestone, and pozzolan, maybe due to the fact that the method used in this study is rather conceived for soils (Pansu and Gautheyrou 2006). Indeed, according to the point of zero salt effect (PZSE) test, material surfaces have an acidic character (Table 1) which confers AEC, higher in the cases of dolomite and anthracite coal.

\section{$\mathrm{NaCl}$ removal efficiency}

As shown in Fig. 2, removal efficiency substantially varied depending on the nature of the element $(\mathrm{Cl}$ or $\mathrm{Na})$, the material (anthracite coal, dolomite, limestone, and pozzolan) and the added $\mathrm{NaCl}$ concentration $\left(\mathrm{C}_{1}=150\right.$; $\mathrm{C}_{2}=1500 ; \mathrm{C}_{3}=3000 ;$ and $\left.\mathrm{C}_{4}=5000 \mathrm{mg} \mathrm{L}^{-1} \mathrm{Cl}\right)$.

\section{Removal of $\mathrm{Cl}$}

Anthracite coal and dolomite removed $\mathrm{Cl}$ more efficiently (48 and $59 \%$, respectively) than the other materials (Fig. 2a) at the lowest added $\mathrm{NaCl}$ concentration $\left(\mathrm{C}_{1}\right.$ level), consistent with their higher PZSE (anthracite and dolomite) and AEC values (anthracite) (Table 1). At higher added $\mathrm{NaCl}$ concentrations, it was observed that $\mathrm{Cl}$ sorption capability of materials was not always related to the measured material properties (the same observation was done for $\mathrm{Na}$ sorption). In such conditions, $\mathrm{NaCl}$ sorption is likely to be modulated by the combined action of the material properties and experimental factors $(\mathrm{NaCl}$ initial concentration, temperature, etc.).

Table 1 Characteristics of materials

\begin{tabular}{|c|c|c|c|c|c|c|c|c|}
\hline \multirow[t]{2}{*}{ Material } & \multicolumn{2}{|l|}{$\mathrm{DF}(\%)$} & \multirow{2}{*}{$\begin{array}{l}\text { Porosity } \\
\%\end{array}$} & \multirow{2}{*}{$\begin{array}{l}\text { Surface area } \\
\left(10^{4}\right) \mathrm{m}^{2} \mathrm{~g}^{-1}\end{array}$} & \multirow{2}{*}{$\begin{array}{l}\text { Bulk density } \\
\mathrm{g} \mathrm{cm}^{-3}\end{array}$} & \multirow[t]{2}{*}{ PZSE } & \multirow{2}{*}{$\begin{array}{l}\text { CEC } \\
\mathrm{cmol}_{+} \mathrm{kg}^{-1}\end{array}$} & \multirow{2}{*}{$\begin{array}{l}\text { AEC } \\
\mathrm{cmol}_{-} \mathrm{kg}^{-1}\end{array}$} \\
\hline & $6.3-10 \mathrm{~mm}$ & $10-14 \mathrm{~mm}$ & & & & & & \\
\hline Anthracite coal & 54 & 50 & $\mathrm{NM}$ & 1.67 & 1.56 & 9.04 & 1.38 & 0.08 \\
\hline Dolomite & 28 & 27 & 4 & 0.85 & 3.08 & 9.19 & 0.41 & $<0.05$ \\
\hline Limestone & 27 & 31 & 22 & 0.92 & 2.84 & 8.72 & 0.54 & $<0.05$ \\
\hline Pozzolan & 26 & 28 & 57 & 1.19 & 2.19 & 8.61 & 2.25 & $<0.05$ \\
\hline
\end{tabular}

$\overline{D F}$ Dynamic fragmentation coefficient, $P Z S E$ point of zero salt effect, $C E C$ cation exchange capacity; $A E C$ anion exchange capacity, $N M$ not measured 

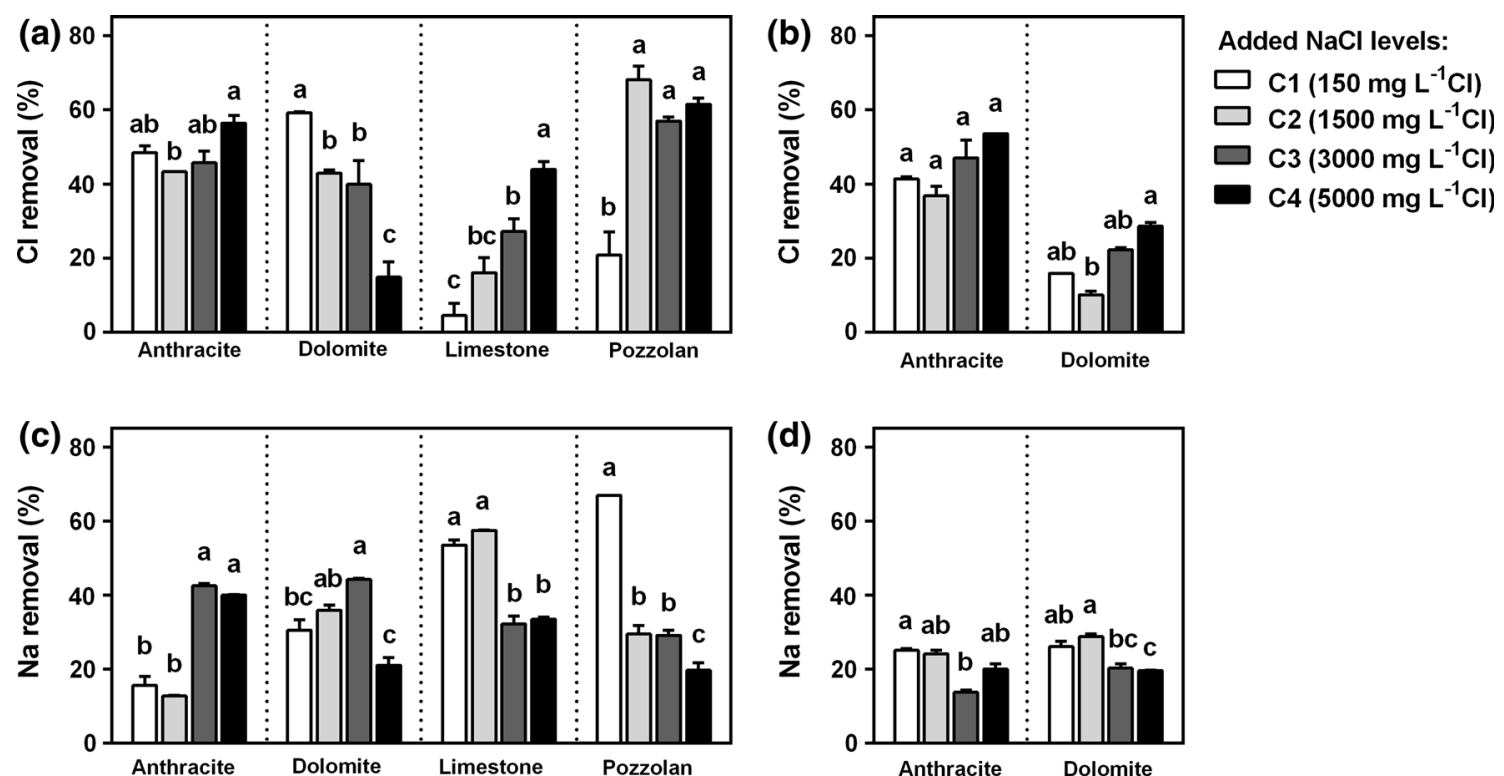

Fig. 2 Removal efficiency of $\mathrm{Cl}(\mathbf{a}, \mathbf{b})$ and $\mathrm{Na}(\mathbf{c}, \mathbf{d})$ in batch assays onto anthracite coal, dolomite, limestone, and pozzolan from aqueous solution at $\mathrm{C}_{1}, \mathrm{C}_{2}, \mathrm{C}_{3}$, and $\mathrm{C}_{4}$ levels $(150,1500,3000$, and

At $\mathrm{C}_{2}, \mathrm{C}_{3}$, and $\mathrm{C}_{4}$ levels, $\mathrm{Cl}$ removal onto anthracite coal remained almost constant (ranging from 43 to $56 \%$ ) and showed no linear relation to the added $\mathrm{NaCl}$ level. This may confer a good efficiency following pulses of high salinity often occurring during storm events. In the case of dolomite, $\mathrm{Cl}$ removal efficiency was satisfactory but negatively related to the added $\mathrm{NaCl}$ level: $59 \%\left(\mathrm{C}_{1}\right)>43 \%$ $\left(\mathrm{C}_{2}\right)=40 \%\left(\mathrm{C}_{3}\right)>15 \%\left(\mathrm{C}_{4}\right)$. At $4{ }^{\circ} \mathrm{C}$ (Fig. $2 \mathrm{~b}$ ), and lower efficiency was found on dolomite (ranging from 10 to $29 \%$ ) with respect to that observed at $22{ }^{\circ} \mathrm{C}$ while was similar on anthracite coal (37-54\%). So it can be inferred that effectiveness of dolomite for $\mathrm{Cl}$ removal may be reduced during winter season, but satisfactory in the case of anthracite coal. Low and very low $\mathrm{Cl}$ percentages were removed onto pozzolan $(21 \%)$ and limestone $(4 \%)$ at $\mathrm{C}_{1}$ level. Nonetheless, removal efficiency increased with rising the added $\mathrm{NaCl}$ concentration. Thus, at $\mathrm{C}_{2}$ to $\mathrm{C}_{4}$ levels pozzolan showed the highest $\mathrm{Cl}$ removal efficiency (from 61 to $68 \%$ ), with values consistent to those previously reported (Al-Rawajfeh et al. 2013), followed by limestone (from 16 to $45 \%$ ). Al-Rawajfeh et al. (2013), studying Cl sorption onto pozzolan, argued that at low added $\mathrm{NaCl}$ concentrations, $\mathrm{Cl}$ sorption may be independent of the added $\mathrm{NaCl}$ concentration because of number-of-ions to available-surface-area ratio is low. However, at higher added $\mathrm{NaCl}$ concentrations the available sorption sites decreases, which may explain the $\mathrm{Cl}$ sorption becomes dependent on the initial concentration.

Experimental data (expressed in $\mathrm{mg} \mathrm{g}^{-1}$ ) at $22{ }^{\circ} \mathrm{C}$ were described using Langmuir and Freundlich sorption isotherm models (Fig. 3). Isotherm constants and regression

$5000 \mathrm{mg} \mathrm{L}^{-1} \mathrm{Cl}$, respectively) at $22{ }^{\circ} \mathrm{C}(\mathbf{a}, \mathbf{c})$ and $4{ }^{\circ} \mathrm{C}(\mathbf{b}, \mathbf{d})$. Different letters indicate significant differences among levels at $p<0.05$ after one-way ANOVA

coefficients, obtained by nonlinear regression, are reported in Table 2. Freundlich was the model that best fit the sorption data on anthracite coal, limestone, and pozzolan, but Langmuir on dolomite (Table 2). The goodness of fit (expressed by the coefficient of determination, $R^{2}$ ) was generally satisfactory, being poor for dolomite. The two models, Freundlich and Langmuir, fit well in the case of $\mathrm{Cl}$ sorption onto anthracite coal and pozzolan. The Freundlich $1 / n$ parameter indicates the strength of the sorption process. Values of $1 / n$ for $\mathrm{Cl}$ showed that on anthracite coal, limestone, and pozzolan a cooperative sorption is likely to occur, revealed by S-isotherms, in which solute-solute forces are stronger than those between solute and substrate (Giles et al. 1974). Values of the $R_{\mathrm{L}}$ Langmuir equilibrium parameter were in the range of $0<R_{\mathrm{L}}<1$ which indicates a favourable sorption process. The Langmuir parameter of $q_{\mathrm{e}}^{0}$ is the upper limit for $q_{\mathrm{e}}$ and represents the maximum sorption of the ion determined by the number of reactive surface sorption sites (Bradl 2004). The $q_{\mathrm{e}}^{0}$ values for anthracite coal, limestone, and pozzolan were in the range of 55 and $98 \mathrm{mg} \mathrm{g}^{-1}$, in agreement with the literature ( $\mathrm{Lv}$ et al. 2009).

\section{Removal of $\mathrm{Na}$}

Anthracite coal showed the lowest Na removal efficiency at $\mathrm{C}_{1}$ and $\mathrm{C}_{2}$ levels ( $\sim 15 \%$ ) (Fig. $2 \mathrm{c}$ ), contrary to what was expected by its high CEC (Table 1), but increasing up to $43 \%$ at $\mathrm{C}_{3}$ and $\mathrm{C}_{4}$ levels. Conversely, $\mathrm{Na}$ removal efficiency onto dolomite, limestone, and pozzolan was generally lower when rising the added $\mathrm{NaCl}$ concentration. 
Fig. 3 Freundlich and Langmuir sorption isotherm modelling of $\mathrm{Cl}(\mathbf{a}, \mathbf{c}, \mathbf{e}, \mathbf{g})$ and $\mathrm{Na}(\mathbf{b}, \mathbf{d}, \mathbf{f}, \mathbf{h})$ onto anthracite coal $(\mathbf{a}, \mathbf{b})$, dolomite $(\mathbf{c}, \mathbf{d})$, limestone $(\mathbf{e}, \mathbf{f})$, and pozzolan $(\mathbf{g}, \mathbf{h})$ at $22{ }^{\circ} \mathrm{C}$ using nonlinear regression analysis. Symbols show the experimental data for each material: anthracite coal (filled circle), dolomite (circle), limestone (square) and pozzolan (filled square)
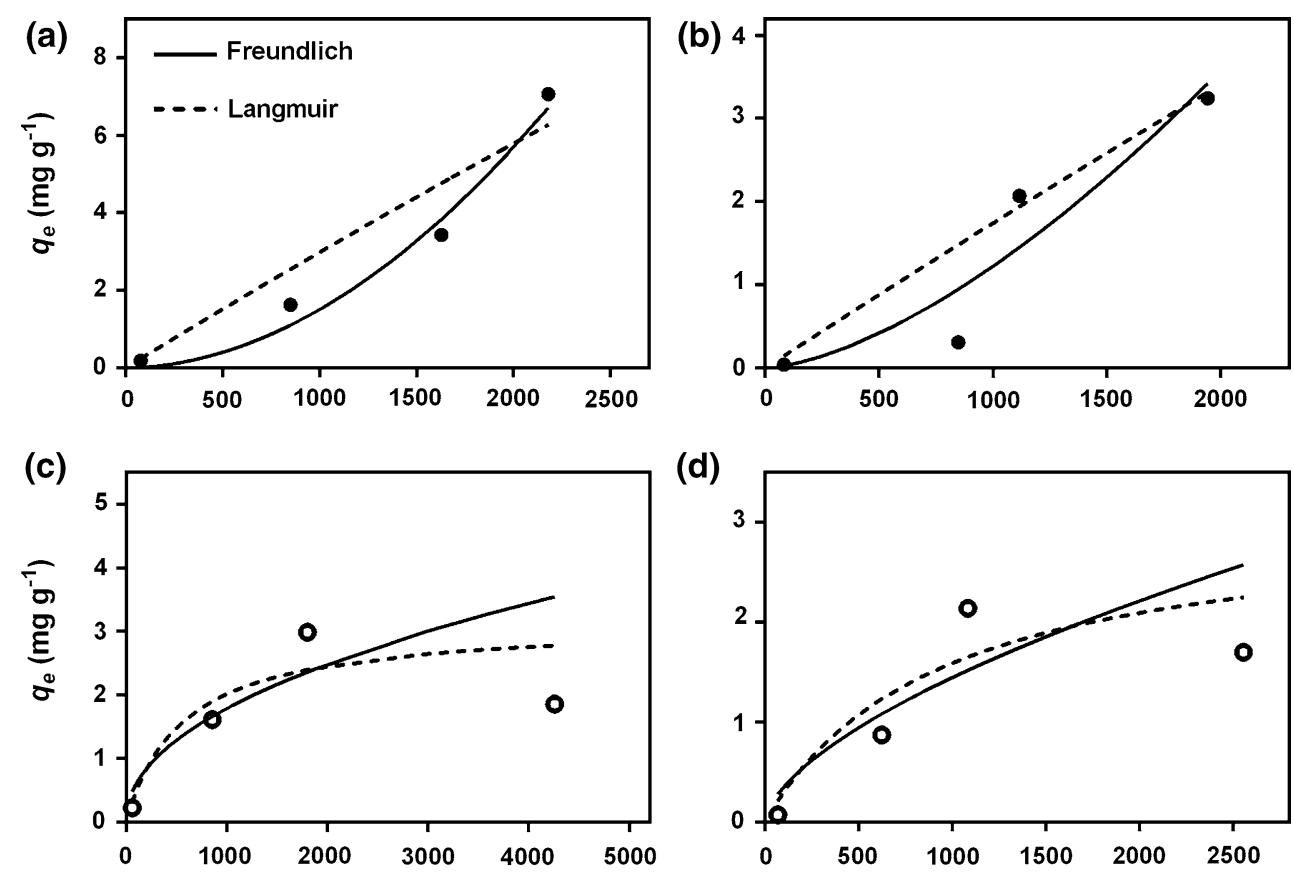

(d)
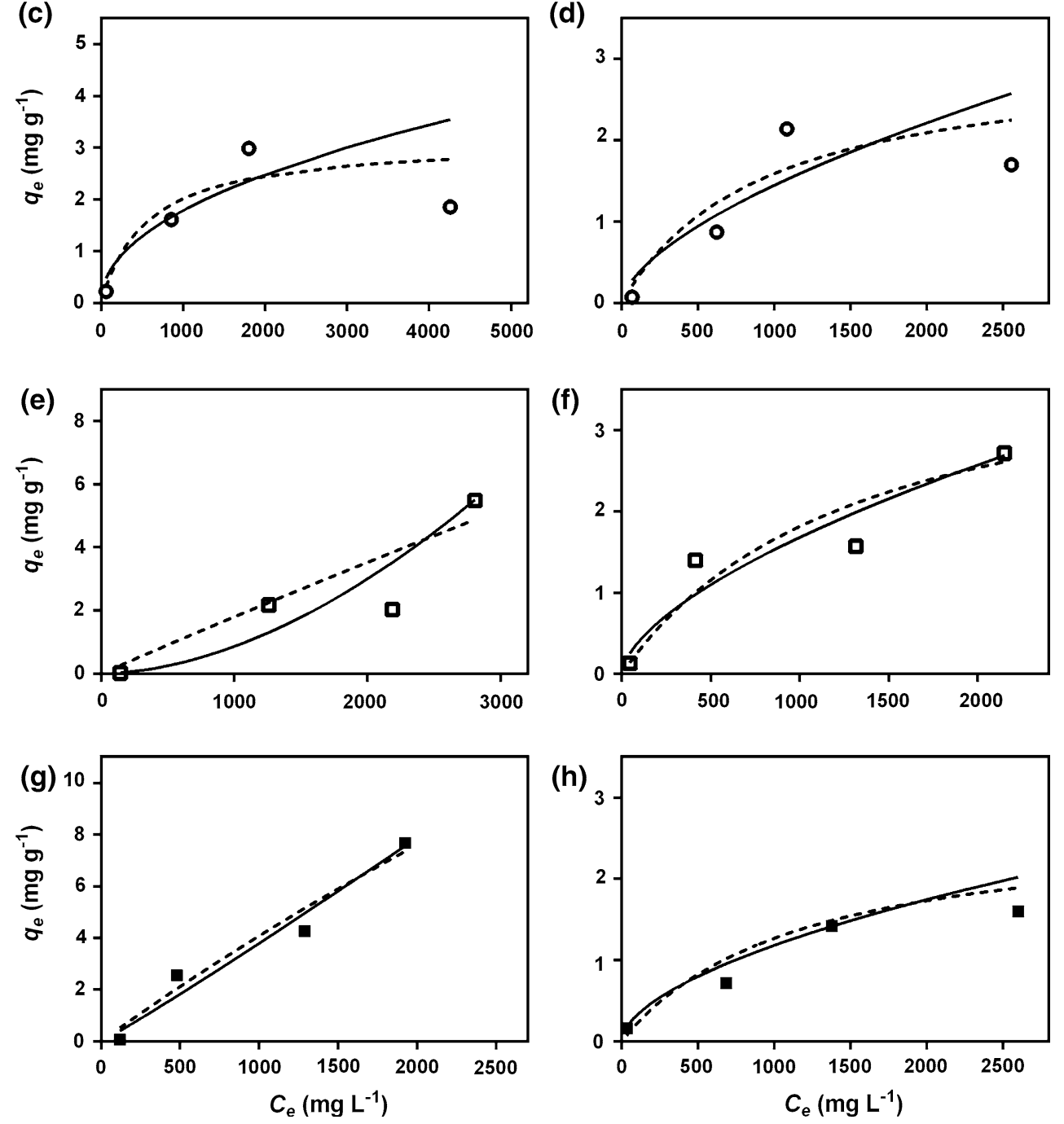

Thus, although $\mathrm{Na}$ was successfully removed onto pozzolan at $\mathrm{C}_{1}$ level $(67 \%)$, Na removal decreased up to threefold at $\mathrm{C}_{4}$ level (20\%). Regarding dolomite, 31-44\% of $\mathrm{Na}$ removal efficiency was accounted at $\mathrm{C}_{1}, \mathrm{C}_{2}$, and $\mathrm{C}_{3}$ levels, decreasing to $21 \%$ at $\mathrm{C}_{4}$ level. About $55 \%$ of $\mathrm{Na}$ was removed onto limestone at $\mathrm{C}_{1}$ and $\mathrm{C}_{2}$ levels for then decreasing by half at $\mathrm{C}_{3}$ and $\mathrm{C}_{4}$ levels $(\sim 33 \%)$. Dissolution processes due to stirring of materials with $\mathrm{NaCl}$ solution in batch are likely to occur which involves the partial destruction of mineral networks and the dissolution of some ions present in minerals (Barral et al. 2014). This would allow $\mathrm{Na}$ ions to be more strongly sorbed, probably by coprecipitation processes (Okumura and Kitano 1986). At very high added $\mathrm{NaCl}$ concentrations (as in $\mathrm{C}_{4}$ level), $\mathrm{Na}$ removal efficiency may be highly affected due to the possible saturation of sorption sites and electrostatic repulsion which deserves further study. At $4{ }^{\circ} \mathrm{C}$ (Fig. 2d), the $\mathrm{Na}$ removal efficiency onto anthracite coal and 
Table 2 Langmuir and Freundlich nonlinear isotherm constants and regression coefficients for $\mathrm{Cl}$ and $\mathrm{Na}(\mathrm{NaCl}$ levels from 150 to $5000 \mathrm{mg} \mathrm{L}^{-1}$ $\mathrm{Cl})$ onto anthracite coal, dolomite, limestone, and pozzolan

\begin{tabular}{|c|c|c|c|c|c|c|}
\hline Element & Model & Parameter & Anthracite coal & Dolomite & Limestone & Pozzolan \\
\hline \multirow[t]{8}{*}{$\mathrm{Cl}$} & \multirow[t]{4}{*}{ Langmuir } & $q_{\mathrm{e}}^{0}\left(\mathrm{mg} \mathrm{g}^{-1}\right)$ & 98.559 & 3.139 & 93.795 & 55.153 \\
\hline & & $K_{\mathrm{L}}\left(\mathrm{L} \mathrm{mg}^{-1}\right)$ & $3.11 \cdot 10^{-5}$ & 0.0018 & $1.95 \cdot 10^{-5}$ & $7.98 \cdot 10^{-5}$ \\
\hline & & $R_{\mathrm{L}}$ & 0.997 & 0.994 & 0.998 & 0.996 \\
\hline & & $R^{2}$ & 0.869 & 0.740 & 0.775 & 0.955 \\
\hline & \multirow[t]{4}{*}{ Freundlich } & $K_{\mathrm{F}}\left(\mathrm{L} \mathrm{mg}^{-1}\right)$ & $2.6 \cdot 10^{-6}$ & $6.79 \cdot 10^{-2}$ & $3.51 \cdot 10^{-6}$ & $2.62 \cdot 10^{-3}$ \\
\hline & & $1 / n$ & 1.920 & 0.473 & 1.797 & 1.053 \\
\hline & & $n$ & 0.521 & 2.113 & 0.561 & 0.949 \\
\hline & & $R^{2}$ & 0.979 & 0.621 & 0.858 & 0.962 \\
\hline \multirow[t]{8}{*}{$\mathrm{Na}$} & \multirow[t]{4}{*}{ Langmuir } & $q_{\mathrm{e}}^{0}\left(\mathrm{mg} \mathrm{g}^{-1}\right)$ & 79.18 & 3.068 & 4.222 & 2.724 \\
\hline & & $K_{\mathrm{L}}\left(\mathrm{L} \mathrm{mg}^{-1}\right)$ & $2.25 \cdot 10^{-5}$ & $1.08 \cdot 10^{-3}$ & $7.52 \cdot 10^{-4}$ & $8.70 \cdot 10^{-4}$ \\
\hline & & $R_{\mathrm{L}}$ & 0.998 & 0.997 & 0.997 & 0.998 \\
\hline & & $R^{2}$ & 0.796 & 0.769 & 0.891 & 0.910 \\
\hline & \multirow[t]{4}{*}{ Freundlich } & $K_{\mathrm{F}}\left(\mathrm{L} \mathrm{mg}^{-1}\right)$ & $2.7 \cdot 10^{-5}$ & 0.021 & 0.024 & 0.024 \\
\hline & & $1 / n$ & 1.549 & 0.615 & 0.614 & 0.563 \\
\hline & & $n$ & 0.646 & 1.052 & 1.320 & 1.729 \\
\hline & & $R^{2}$ & 0.883 & 0.698 & 0.904 & 0.891 \\
\hline
\end{tabular}

dolomite was moderate (24-29\%) with a slight trend to decrease (14-20\%) with rising the added $\mathrm{NaCl}$ concentration. As for $\mathrm{Cl}$, Freundlich was the model that best fit $\mathrm{Na}$ sorption data on anthracite coal, limestone and pozzolan, while Langmuir on dolomite (Fig. 3; Table 2). The $1 / n$ and $n$ values indicated a favourable sorption onto dolomite, limestone, and pozzolan $(1 / n<1, n=1-10)$. Values of the $R_{\mathrm{L}}$ were in the range of $0<R_{\mathrm{L}}<1$, indicating a favourable sorption process. The $q_{\mathrm{e}}^{0}$ values ranged from 3 to $4 \mathrm{mg} \mathrm{g}^{-1}$ (except pozzolan, $79 \mathrm{mg} \mathrm{g}^{-1}$ ), consistent with those observed by others authors $\left(\sim 2-6 \mathrm{mg} \mathrm{Na}^{+} \mathrm{g}^{-1}\right.$ ) studying $\mathrm{Na}$ sorption on calcite (Ishikawa and Ichikuni 1984).

\section{Multipollution scenario: $\mathrm{NaCl}$ and trace metal removal}

In order to evaluate on laboratory the practical applicability of the materials as reactive media in field installations (FB), a synthetic runoff solution ( $\mathrm{NaCl}$ and metals) was passed through columns filled with each of the materials for 20 days. The removal efficiency of $\mathrm{Cl}, \mathrm{Na}, \mathrm{Cd}, \mathrm{Cu}, \mathrm{Ni}$, and $\mathrm{Zn}$ onto the materials at the $\mathrm{C}_{1}$ level $\left(150 \mathrm{mg} \mathrm{L}^{-1} \mathrm{Cl}\right)$ over the 20 days of column assay is shown in Fig. 4 and the $\mathrm{pH}$ values in the Table 3. Chloride and $\mathrm{Na}$ removal efficiency was greatly reduced in column assays with respect to that observed in batch. Overall, the highest $\mathrm{Cl}$ and $\mathrm{Na}$ removal efficiency was reached onto dolomite, followed by limestone, and ultimately anthracite coal and pozzolan as follows: (1) <1, 1-30, <1-20 and $<1-1 \%$ removed $\mathrm{Cl}$; and (2) 1-8, 2-9, 2-7 and $<1-3 \%$ removed $\mathrm{Na}$ (anthracite coal, dolomite, limestone, and pozzolan, respectively). Indeed, dissimilarities between static (batch assays) and dynamic conditions (column assays) are expected. This is due to the fact that the pollutant solutionphase concentration ( $\mathrm{NaCl}$ and metals) is continuously increasing in the column system (Goel et al. 2005), so the equilibrium is never achieved. In fact, this behaviour is expected to occur in a field installation (filter bed) that continuously receives road runoff. As shown in Fig. 4, $\mathrm{NaCl}$ removal stabilizes within the studied time, generally before 3 days. Considering the high solubility of $\mathrm{NaCl}$ in water, we believe that the results are very encouraging.

One of the challenges of active underground FBs is not only the removal of de-icing salts from road runoff but also trace metals, considering the interaction among them. A competitive binding of metal ions (included into the synthetic runoff solution) to the reactive surface sorption sites may explain the observed differences in the present study between batch (static, only $\mathrm{NaCl}$ ) and column assays (dynamic, $\mathrm{NaCl}$ and trace metals). Also, the formation of soluble chlorocomplexes with metals may account for the highly decrease on $\mathrm{Cl}$ removal. The role played by other anions besides $\mathrm{Cl}^{-}$on metal complexation was not considered as its presence in the solutions was very low (or even lower than the detection limit): (1) $5.5 \mathrm{mg} \mathrm{L}^{-1}$ or $15.6 \mathrm{mg} \mathrm{L}^{-1} \mathrm{SO}_{4}{ }^{2-}$ at day 0 (solutions in contact with anthracite coal and dolomite, respectively) decreasing to $0.2 \mathrm{mg} \mathrm{L}^{-1}$ at day 1 ; (2) $\mathrm{HCO}_{3}^{-}$up to $2 \mathrm{mg} \mathrm{L}^{-1}$ (limestone); and (3) $\mathrm{NO}_{2}{ }^{-}$up to $0.4 \mathrm{mg} \mathrm{L}^{-1}$ (limestone). A combination of materials should be investigated for improving the removal efficiency of $\mathrm{NaCl}$ and trace metals simultaneously, as previously proposed for mixtures of pollutants (Reddy et al. 2014).

Trace metal removal efficiency was generally high, as usually reported (Reddy et al. 2014), although large 

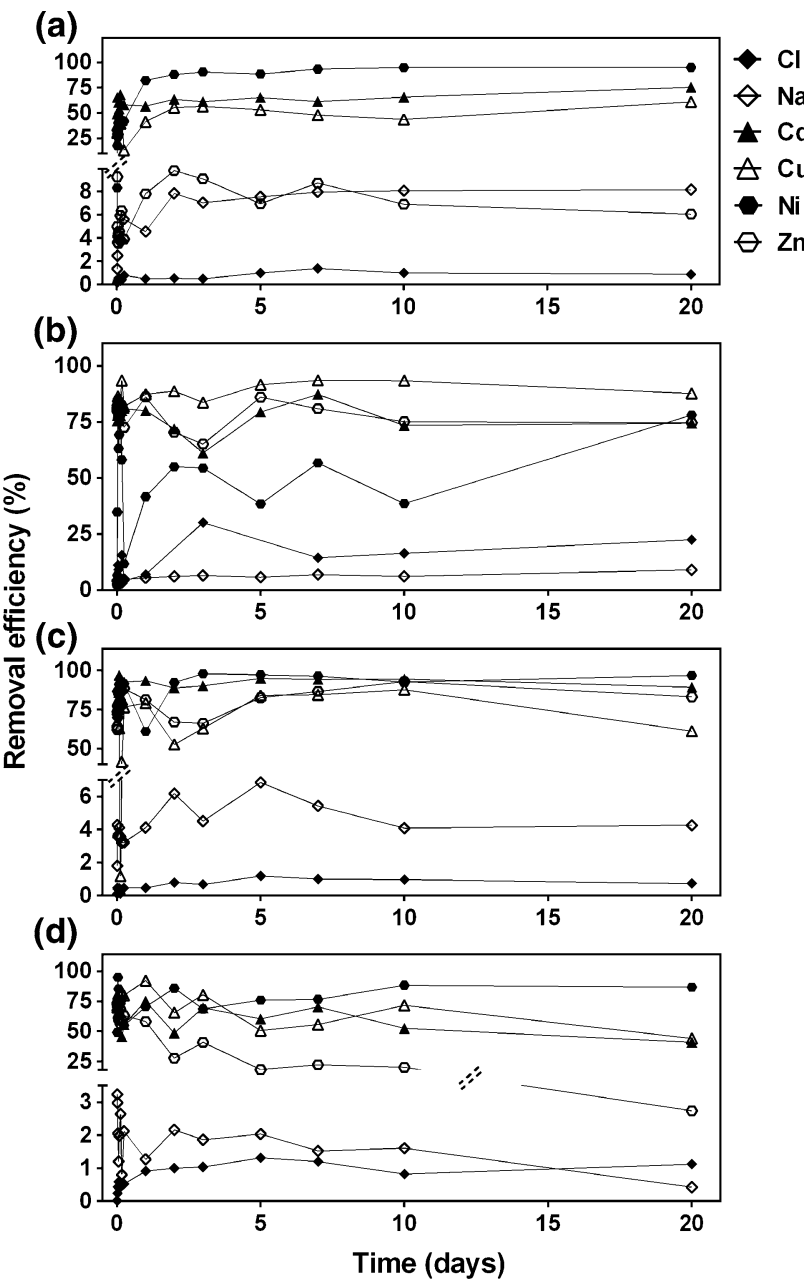

Fig. 4 Removal efficiency of $\mathrm{Cl}, \mathrm{Na}, \mathrm{Cd}, \mathrm{Cu}, \mathrm{Ni}$, and $\mathrm{Zn}$ over time (up to 20 days) in column assays performed with a synthetic runoff solution with $\mathrm{NaCl}\left(\mathrm{C}_{1}\right.$ level $\left.=150 \mathrm{mg} \mathrm{L}^{-1} \mathrm{Cl}\right)$ and trace metals $(2$ $\mathrm{Cd}, 20 \mathrm{Cu}, 3 \mathrm{Ni}$, and $300 \mathrm{Zn} \mu \mathrm{g} \mathrm{L}^{-1}$ ) onto anthracite coal (a), dolomite (b), limestone (c), and pozzolan (d)

differences were observed depending on the material. As shown in Table 3, higher $\mathrm{pH}$ values in the solutions collected from the column system with dolomite were found (from 7.7 to 8.2), followed by limestone (from 6.8 to 7.3), pozzolan (from 6.7 to 5.8), and anthracite coal (from 4.6 to 5.7). From these data, the highest trace metal removal efficiency onto dolomite and limestone is expected. Indeed, at day 20 the sequence of metal removal efficiency was as follows: (1) $\mathrm{Ni}(95 \%)>\mathrm{Cd}(75 \%)>\mathrm{Cu}(61 \%) \gg \mathrm{Zn}$ $(6 \%)$ onto anthracite coal; (2) $\mathrm{Cu} \quad(88 \%)>\mathrm{Ni}$ $(78 \%)>\mathrm{Zn}(75 \%) \sim \mathrm{Cd}(74 \%)$ onto dolomite; (3) $\mathrm{Ni}$ $(97 \%)>\mathrm{Cd} \quad(89 \%)>\mathrm{Zn} \quad(83 \%)>\mathrm{Cu} \quad(61 \%)$ onto limestone; and (4) $\mathrm{Ni} \quad(87 \%)>\mathrm{Cu} \quad(44 \%)>\mathrm{Cd}$ $(41 \%) \gg \mathrm{Zn}(3 \%)$ onto pozzolan. A criterion in the material choice should be to show an adequate metallic removal efficiency that remains over time. In this regard, the values of metal removal efficiency followed a general
Table $3 \mathrm{pH}$ values of the individual solutions collected at different times in the column assays performed with a synthetic runoff solution with $\mathrm{NaCl}\left(\mathrm{C}_{1}\right.$ level $\left.=150 \mathrm{mg} \mathrm{L}^{-1} \mathrm{Cl}\right)$ and trace metals $(2 \mathrm{Cd}, 20$ $\mathrm{Cu}, 3 \mathrm{Ni}$, and $300 \mathrm{Zn} \mu \mathrm{g} \mathrm{L}^{-1}$ ) for each of the four selected materials (anthracite coal, dolomite, limestone, and pozzolan)

\begin{tabular}{lllll}
\hline Time (days) & Anthracite coal & Dolomite & Limestone & Pozzolan \\
\hline 0 & 4.6 & 7.7 & 6.8 & 6.7 \\
0.01 & 4.2 & 7.9 & 7.0 & 6.7 \\
0.02 & 4.2 & 8.1 & 7.1 & 7.0 \\
0.04 & 4.1 & 8.1 & 7.2 & 7.1 \\
0.06 & 4.1 & 8.2 & 7.2 & 6.7 \\
0.08 & 4.1 & 8.1 & 7.2 & 6.6 \\
0.13 & 4.2 & 8.2 & 7.4 & 6.7 \\
0.17 & 4.3 & 8.3 & 7.2 & 6.7 \\
0.25 & 4.3 & 8.3 & 7.3 & 6.7 \\
1 & 4.8 & 8.4 & 7.2 & 6.6 \\
2 & 5.1 & 8.3 & 7.3 & 6.8 \\
3 & 5.3 & 8.3 & 7.1 & 6.5 \\
5 & 5.5 & 8.3 & 7.3 & 6.6 \\
7 & 5.6 & 8.2 & 7.3 & 6.3 \\
10 & 5.5 & 8.3 & 7.2 & 6.3 \\
20 & 5.7 & 8.3 & 7.3 & 5.8 \\
\hline
\end{tabular}

trend towards equilibrium from 2 to 5 days of contact time (Fig. 4) except the case of pozzolan. At the end of the experiment (day 20), the removal efficiency of $\mathrm{Ni}, \mathrm{Cd}$, and $\mathrm{Cu}$ onto anthracite coal was $11.5,2.0$, and 1.5-fold, respectively, higher than at the beginning (day 0) (Fig. 4a). A moderate decline was noted in the case of $\mathrm{Zn}$. Similar patterns were observed in the case of dolomite (Fig. 4b), although with a much smaller increase for $\mathrm{Ni}$ at day 20 of the experiment (2.2-fold) without reaching equilibrium during the experienced time. In the case of limestone (Fig. 4c), metal removal efficiency was higher (case of $\mathrm{Cd}$, $\mathrm{Ni}$, and $\mathrm{Zn}$ ) at the end of the experiment; $\mathrm{Cu}$ removal remaining constant over time. While in general the removal efficiency onto anthracite coal, dolomite, and limestone shows an upward trend (or remains constant) over time, metal removal efficiency onto pozzolan declined progressively. Thus, a very high decrease on $\mathrm{Na}, \mathrm{Cd}, \mathrm{Cu}$, and $\mathrm{Zn}$ removal efficiency onto pozzolan (up to 0.04-fold) was observed over time (Fig. 4d). The progressive decrease observed in the $\mathrm{pH}$ values in the solutions in contact with pozzolan over time (Table 3 ) may account for this result. This makes pozzolan should not be considered as a suitable candidate material for the purpose of the present study.

As indicated, $\mathrm{pH}$ plays a key role in removal efficiency. The surface charge of materials becomes more negative with increasing $\mathrm{pH}$ and attracts metal cations for sorption. Moreover, with increasing $\mathrm{pH}$ the proportion of hydrolyzed metal species rises, which are more strongly sorbed than 
Table 4 Predicted percentages with Visual Minteq of the different chemical species of $\mathrm{Cl}, \mathrm{Na}, \mathrm{Cd}, \mathrm{Cu}, \mathrm{Ni}$, and $\mathrm{Zn}$ in the individual solutions collected at 0,1 , and 20 days in the column assays performed with a synthetic runoff solution with $\mathrm{NaCl}\left(\mathrm{C}_{1}\right.$ level $\left.=150 \mathrm{mg} \mathrm{L}^{-1} \mathrm{Cl}\right)$ and trace metals $(2 \mathrm{Cd}, 20 \mathrm{Cu}, 3 \mathrm{Ni}$, and $300 \mathrm{Zn} \mu \mathrm{g} \mathrm{L}^{-1}$ ) for each of the four selected materials (anthracite coal, dolomite, limestone, and pozzolan)

\begin{tabular}{|c|c|c|c|c|c|c|c|c|c|c|c|c|c|}
\hline \multirow[t]{2}{*}{ Element } & \multirow[t]{2}{*}{ Chemical specie } & \multicolumn{3}{|c|}{ Anthracite coal } & \multicolumn{3}{|c|}{ Dolomite } & \multicolumn{3}{|c|}{ Limestone } & \multicolumn{3}{|c|}{ Pozzolan } \\
\hline & & 0 & 1 & 20 & 0 & 1 & 20 & 0 & 1 & 20 & 0 & 1 & 20 \\
\hline $\mathrm{Cl}$ & $\mathrm{Cl}^{-}$ & 99.8 & 99.8 & 99.8 & 99.8 & 99.8 & 99.8 & 99.8 & 99.8 & 99.8 & 99.8 & 99.8 & 99.8 \\
\hline \multirow[t]{5}{*}{$\mathrm{Na}$} & $\mathrm{Na}^{+}$ & 99.8 & 99.8 & 99.8 & 99.8 & 99.8 & 99.9 & 99.8 & 99.8 & 99.8 & 99.8 & 99.8 & 99.8 \\
\hline & $\mathrm{NaSO}_{4}^{-}$ & 1.7 & 1.6 & $<0.1$ & 1.7 & 1.7 & $<0.1$ & $<0.1$ & $<0.1$ & $<0.1$ & 1.7 & $<0.1$ & $<0.1$ \\
\hline & $\mathrm{NaCl}(\mathrm{aq})$ & 0.4 & 0.4 & 0.4 & 0.4 & 0.3 & 0.3 & 0.4 & 0.4 & 0.4 & 0.4 & 0.4 & 0.4 \\
\hline & $\mathrm{NaHCO}_{3}(\mathrm{aq})$ & $<0.1$ & $<0.1$ & $<0.1$ & 0.2 & $<0.1$ & $<0.1$ & 0.2 & $<0.1$ & $<0.1$ & 0.2 & $<0.1$ & $<0.1$ \\
\hline & $\mathrm{NaCO}_{3}{ }^{-}$ & $<0.1$ & $<0.1$ & $<0.1$ & 0.1 & $<0.1$ & $<0.1$ & $<0.1$ & $<0.1$ & $<0.1$ & $<0.1$ & $<0.1$ & $<0.1$ \\
\hline \multirow[t]{6}{*}{$\mathrm{Cd}$} & $\mathrm{Cd}^{2+}$ & 75.9 & 76.4 & 76.4 & 74.3 & 77.2 & 80.3 & 76.1 & 76.4 & 76.4 & 75.8 & 76.5 & 76.6 \\
\hline & $\mathrm{CdOH}^{+}$ & $<0.1$ & $<0.1$ & $<0.1$ & 1.8 & $<0.1$ & $<0.1$ & 0.4 & $<0.1$ & $<0.1$ & 0.7 & $<0.1$ & $<0.1$ \\
\hline & $\mathrm{CdCl}^{+}$ & 23.0 & 23.2 & 23.2 & 21.8 & 22.0 & 19.4 & 23.1 & 23.2 & 23.2 & 23.1 & 23.1 & 23.1 \\
\hline & $\mathrm{CdCl}_{2}(a q)$ & 0.4 & 0.4 & 0.4 & 0.3 & 0.3 & 0.2 & 0.4 & 0.4 & 0.4 & 0.4 & 0.4 & 0.3 \\
\hline & $\mathrm{CdCO}_{3}(a q)$ & $<0.1$ & $<0.1$ & $<0.1$ & 0.1 & $<0.1$ & $<0.1$ & $<0.1$ & $<0.1$ & $<0.1$ & $<0.1$ & $<0.1$ & $<0.1$ \\
\hline & $\mathrm{CdSO}_{4}(a q)$ & 0.8 & $<0.1$ & $<0.1$ & 1.6 & 0.5 & $<0.1$ & $<0.1$ & $<0.1$ & $<0.1$ & $<0.1$ & $<0.1$ & $<0.1$ \\
\hline \multirow[t]{8}{*}{$\mathrm{Cu}$} & $\mathrm{Cu}^{2+}$ & 81.4 & 83.1 & 82.6 & 5.7 & 79.5 & 79.9 & 27.4 & 80.3 & 81.0 & 18.6 & 80.5 & 83.1 \\
\hline & $\mathrm{CuOH}^{+}$ & 17.0 & 16.1 & 16.7 & 55.3 & 19.2 & 19.4 & 62.1 & 18.8 & 18.2 & 64.8 & 18.7 & 16.1 \\
\hline & $\mathrm{Cu}(\mathrm{OH})_{2}(a q)$ & 0.2 & 0.2 & 0.2 & 36.1 & 0.3 & 0.3 & 9.4 & 0.3 & 0.3 & 15.1 & 0.3 & 0.2 \\
\hline & $\mathrm{Cu}_{2}(\mathrm{OH})_{2}^{2+}$ & $<0.1$ & $<0.1$ & $<0.1$ & 0.1 & $<0.1$ & $<0.1$ & 0.2 & $<0.1$ & $<0.1$ & 0.4 & $<0.1$ & $<0.1$ \\
\hline & $\mathrm{Cu}(\mathrm{OH})_{3}^{-}$ & $<0.1$ & $<0.1$ & $<0.1$ & 0.6 & $<0.1$ & $<0.1$ & $<0.1$ & $<0.1$ & $<0.1$ & 0.1 & $<0.1$ & $<0.1$ \\
\hline & $\mathrm{CuCl}^{+}$ & 0.5 & 0.5 & 0.5 & $<0.1$ & 0.5 & 0.4 & 0.2 & 0.5 & 0.5 & 0.1 & 0.5 & 0.5 \\
\hline & $\mathrm{CuCO}_{3}(a q)$ & $<0.1$ & $<0.1$ & $<0.1$ & 2.1 & $<0.1$ & $<0.1$ & 0.6 & $<0.1$ & $<0.1$ & 1.0 & $<0.1$ & $<0.1$ \\
\hline & $\mathrm{CuSO}_{4}(a q)$ & 0.8 & $<0.1$ & $<0.1$ & 0.1 & 0.5 & $<0.1$ & $<0.1$ & $<0.1$ & $<0.1$ & $<0.1$ & $<0.1$ & $<0.1$ \\
\hline \multirow[t]{6}{*}{$\mathrm{Ni}$} & $\mathrm{Ni}^{2+}$ & 98.9 & 99.8 & 99.8 & 93.3 & 99.3 & 99.8 & 98.9 & 99.8 & 99.8 & 98.3 & 99.8 & 99.8 \\
\hline & $\mathrm{NiOH}^{+}$ & 0.1 & 0.1 & 0.1 & 3.6 & 0.1 & 0.1 & 0.9 & 0.1 & 0.1 & 1.4 & 0.1 & 0.1 \\
\hline & $\mathrm{Ni}(\mathrm{OH})_{2}(a q)$ & $<0.1$ & $<0.1$ & $<0.1$ & 1.0 & $<0.1$ & $<0.1$ & 0.1 & $<0.1$ & $<0.1$ & 0.1 & $<0.1$ & $<0.1$ \\
\hline & $\mathrm{NiCl}^{+}$ & 0.1 & 0.1 & 0.1 & 0.1 & 0.1 & 0.1 & 0.1 & 0.1 & 0.1 & 0.1 & 0.1 & 0.1 \\
\hline & $\mathrm{NiCO}_{3}(a q)$ & $<0.1$ & $<0.1$ & $<0.1$ & 0.2 & $<0.1$ & $<0.1$ & $<0.1$ & $<0.1$ & $<0.1$ & $<0.1$ & $<0.1$ & $<0.1$ \\
\hline & $\mathrm{NiSO}_{4}(a q)$ & 0.9 & $<0.1$ & $<0.1$ & 1.7 & 0.5 & $<0.1$ & $<0.1$ & $<0.1$ & $<0.1$ & $<0.1$ & $<0.1$ & $<0.1$ \\
\hline \multirow[t]{6}{*}{$\mathrm{Zn}$} & $\mathrm{Zn}^{2+}$ & 97.5 & 98.4 & 98.4 & 36.7 & 97.7 & 98.4 & 86.6 & 98.3 & 98.3 & 77.1 & 98.3 & 98.4 \\
\hline & $\mathrm{ZnOH}^{+}$ & 0.6 & 0.6 & 0.6 & 11.3 & 0.7 & 0.8 & 6.2 & 0.7 & 0.7 & 8.5 & 0.7 & 0.6 \\
\hline & $\mathrm{Zn}(\mathrm{OH})_{2}(a q)$ & 0.1 & 0.1 & 0.1 & 50.8 & 0.1 & 0.1 & 6.4 & 0.1 & 0.1 & 13.6 & 0.1 & 0.1 \\
\hline & $\mathrm{ZnCl}^{+}$ & 0.9 & 0.9 & 0.9 & 0.3 & 0.8 & 0.7 & 0.8 & 0.9 & 0.9 & 0.7 & 0.9 & 0.9 \\
\hline & $\mathrm{ZnCO}_{3}(a q)$ & $<0.1$ & $<0.1$ & $<0.1$ & 0.1 & $<0.1$ & $<0.1$ & $<0.1$ & $<0.1$ & $<0.1$ & $<0.1$ & $<0.1$ & $<0.1$ \\
\hline & $\mathrm{ZnSO}_{4}(a q)$ & 1.0 & 0.1 & $<0.1$ & 0.7 & 0.6 & $<0.1$ & $<0.1$ & $<0.1$ & $<0.1$ & $<0.1$ & $<0.1$ & $<0.1$ \\
\hline
\end{tabular}

the free metal ions. The predicted percentage of the different chemical species of $\mathrm{Cl}, \mathrm{Na}, \mathrm{Cd}, \mathrm{Cu}, \mathrm{Ni}$, and $\mathrm{Zn}$ in the individual solutions collected at 0,1 , and 20 days from the experimental systems was calculated (Table 4). Intermediate times were not included for reasons of space. Almost $100 \%$ of the $\mathrm{Cl}$ and $\mathrm{Na}$ species were in the form of free ion $\left(\mathrm{Cl}^{-}\right.$and $\left.\mathrm{Na}^{+}\right)$, and only a minor proportion was as $\mathrm{NaCl}$ (aq) $(\sim 0.4 \%)$ and $\mathrm{NaSO}_{4}^{-}$(up to $2 \%$ ), partially explaining the low $\mathrm{Cl}$ and $\mathrm{Na}$ removal efficiency. About 74-80\% of $\mathrm{Cd}$ species were in the form of free ion $\left(\mathrm{Cd}^{2+}\right)$. At the low added $\mathrm{Cd}$ concentration of the present study
(2 $\left.\mu \mathrm{g} \mathrm{L}^{-1}\right)$, chemisorption processes (ion exchange) of $\mathrm{Cd}^{2+}$ onto materials are likely to occur rather than precipitation ones (Bradl 2004). Besides $\mathrm{Cd}^{2+}$, chlorocomplexes $\left(\mathrm{CdCl}^{+}\right)$were also present ( $\left.19-23 \%\right)$, being less strongly sorbed than $\mathrm{Cd}^{2+}$, which may explain the lower $\mathrm{Cd}$ removal than that observed for $\mathrm{Cu}$ and $\mathrm{Ni}$. Also, $\mathrm{Cd}$ displacement by $\mathrm{Cl}$ ions was evidenced (Bäckström et al. 2004). $\mathrm{Cu}^{2+}$ was the predominant $\mathrm{Cu}$ specie $(80-83 \%)$ from the beginning (case of anthracite coal) or from day 1 (dolomite, limestone, and pozzolan). Hydrolyzed species are important at day 0 except in solutions in contact with 
anthracite coal: $55-65 \% \mathrm{CuOH}^{+}$(dolomite, limestone, and pozzolan) and $36 \% \mathrm{Cu}(\mathrm{OH})_{2}(a q)$ (dolomite). The very high proportion of hydrolyzed $\mathrm{Cu}$ species at $\mathrm{pH} \geq 8$ explains the higher $\mathrm{Cu}$ removal onto dolomite. Nearly $100 \%$ of the $\mathrm{Ni}$ species were in the form of free ion $\left(\mathrm{Ni}^{2+}\right)$, and a minor proportion were in a chloro-, sulfo- and hydroxocomplex form (anthracite coal and dolomite, day 0 ), suggesting non-specific adsorption. Hydrolyzed species of $\mathrm{Zn}\left[\mathrm{ZnOH}^{+}, \mathrm{Zn}(\mathrm{OH})_{2}(a q)\right]$ appeared from day 1 (dolomite, limestone, and pozzolan), mainly in the case of dolomite $\left[51 \% \mathrm{Zn}(\mathrm{OH})_{2}(a q)\right]$ explaining the higher $\mathrm{Zn}$ removal onto this material.

\section{Conclusion}

Results showed that dolomite has the best physical properties for minimizing fragmentation processes, essential to maximize filter bed effectiveness during construction and maintenance. Anthracite coal and dolomite were the most efficient in removing $\mathrm{Cl}$ ions at the lowest added $\mathrm{NaCl}$ concentration $\left(150 \mathrm{mg} \mathrm{L}^{-1} \mathrm{Cl}\right)$. At higher levels (1500-5000 mg L ${ }^{-1} \mathrm{Cl}$ ), Cl removal onto anthracite coal remained constant but decreased onto dolomite. Although low $\mathrm{Cl}$ percentage was removed onto pozzolan and limestone at low $\mathrm{NaCl}$ concentration, removal efficiency highly increased with rising the added $\mathrm{NaCl}$ concentration. Conversely, limestone and pozzolan were the most efficient in $\mathrm{Na}$ removal at low added $\mathrm{NaCl}$ concentration. With rising the $\mathrm{NaCl}$ concentration, $\mathrm{Na}$ removal efficiency onto anthracite coal increased, while it decreases onto the other materials. The experiments at $4{ }^{\circ} \mathrm{C}$ showed lower $\mathrm{Cl}$ and $\mathrm{Na}$ removal than at $22{ }^{\circ} \mathrm{C}$, anthracite coal removing $\mathrm{NaCl}$ more efficiently than dolomite. In all cases, anthracite coal showed a higher potential effectiveness against salinity pulses and low temperatures. The multipollution scenario showed that $\mathrm{NaCl}$ removal efficiency is lower in column assays with respect to batch, attributed to the continuously increase in $\mathrm{NaCl}$ concentration, the competitive binding of metals for sorption sites, and the formation of soluble metallic chlorocomplexes. The highest $\mathrm{NaCl}$ removal in column assays was reached onto dolomite, followed by limestone, and ultimately by anthracite coal and pozzolan. A very high trace metal removal efficiency was noted and remained over time, except in the case of pozzolan. Further studies could include a combination of materials, taking advantage of their physical properties and multielemental removal efficiency at low or moderate initial concentrations. Also, further studies aiming to material regeneration in field facilities in the medium/long term could be very interesting.

Acknowledgments This research was supported by the Autoroute du Sud de la France Company (ASF). The authors especially wish to thank Christophe Anzoras of Vinci Autoroutes-ASF for technical discussions on the results, Dr. Javier Pérez Esteban for his assistance in the data modelling, and Michel Bisping for his laboratory assistance.

\section{References}

AFNOR (1990) Granulats: essai de fragmentation dynamique NF P 18-574. Association Française de Normalisation

Albadarin AB, Mangwandi C, Al-Muhtaseb AH, Walker GM, Allen SJ, Ahmad MNM (2012) Kinetic and thermodynamics of chromium ions adsorption onto low-cost dolomite adsorbent. Chem Eng J 179:193-202

Al-Rawajfeh AE, Al-Shamaileh EM, Al-Whoosh K, Al-Ma'abrah A, Al-Zorqan R, Zanoon R, Rawajfeh K, Al-Jufout S (2013) Adsorption desalination of chloride ions on composite naturalsynthetic materials: an approach for the reduction of chlorine corrosion in electrodeionization units. $\mathrm{J}$ Ind Eng Chem 19:1895-1902

Aziz HA, Yusoff MS, Adlan MN, Adnan NH, Alias S (2004) Physicochemical removal of iron from semi-aerobic landfill leachate by limestone filter. Waste Manag 24:353-358

Bäckström M, Karlsson S, Bäckman L, Folkeson L, Lind B (2004) Mobilisation of heavy metals by deicing salts in a roadside environment. Water Res 38:720-732

Barral MT, Paradelo R, Liste A, Cancelo-González J, Balufo A, Prieto DM (2014) Reutilization of granite powder as a component of permeable reactive barriers for the treatment of $\mathrm{Cr}(\mathrm{VI})-$ contaminated waters. Span J Soil Sci 4:179-191

Blomqvist $\mathrm{G}$ (2001) De-icing salt and the roadside environment. $\mathrm{PhD}$ Dissertation, Royal Institute of Technology

Bradl HB (2004) Adsorption of heavy metal ions on soils and soils constituents. J Colloid Interface Sci 277:1-18

Cottin N, Merlin G (2010) Fate of chlorinated benzenes in laboratory peat and pozzolana filters. Water Air Soil Pollut 213:425-435

Dai HL, Zhang KL, Xu XL, Yu HY (2012) Evaluation on the effects of deicing chemicals on soil and water environment. Procedia Environ Sci 13:2122-2130

Fuerhacker M, Haile TM, Monai B, Mentler A (2011) Performance of a filtration system equipped with filter media for parking lot runoff treatment. Desalin 275:118-125

Galvez-Cloutier R, Michaux A (2013) Faisabilité de transposition des unités de lit filtrant et marais conçus par U. Laval à des conditions françaises. Essais d'adsorption sur les matériaux pour la garniture du lit filtrant réactif. Technical report, Université Laval

Galvez-Cloutier R, Triffaut-Bouchet G, Roy S (2014) Eco-Engineering process for the treatment of contaminants from salted highway runoff: Adapted wetland and active filter. In: 11th international conference phytotecnologies. Heraklion, Crete

Giles CH, Smith D, Huitson A (1974) A general treatment and classification of the solute adsorption isotherm. I. Theoretical. J Colloid Interface Sci 47:755-765

Goel J, Kadirvelu K, Rajagopal C, Kumar Garg V (2005) Removal of lead(II) by adsorption using treated granular activated carbon: batch and column studies. J Hazard Mater 125:211-220

Green SM, Machin R, Cresser MS (2008) Long-term road salting effects on dispersion of organic matter from roadside soils into drainage water. Chem Ecol 24:221-231

Guesdon G, Galvez R (2012) Faisabilité de transposition des unités de lit filtrant et marais conçus par U. Laval à des conditions françaises. Parties 2: Essaies en vue de la conception du lit filtrant réactif et du marais épurateur construit adapté. Technical report, Université Laval 
Guesdon G, Galvez-Cloutier R, Triffault-Bouchet G (2013) Evaluation pilote d'un marais épurateur construit adapté et d'un lit filtrant réactif pour le traitement du ruisellement routier: Suivi de l'écosystème et résultats de performance. Technical report, Université Laval

Gustafsson JP (2011) Visual MINTEQ, v.3.0. Department of Land and Water Resources Engineering, Royal Institute of Technology, Stockholm. http://www2.1wr.kth.se/English/OurSoftware/ Vminteq/index.htm

Ishikawa M, Ichikuni M (1984) Uptake of sodium and potassium by calcite. Chem Geol 42:137-146

Jiang C, Jia L, Zhang B, He Y, Kirumba G (2014) Comparison of quartz sand, anthracite, shale and biological ceramsite for adsorptive removal of phosphorus from aqueous solution. J Environ Sci 26:466-477

Karaca S, Gürses A, Ejder M, Açikyildiz M (2004) Kinetic modeling of liquid-phase adsorption of phosphate on dolomite. J Colloid Interface Sci 277:257-263

Karadag D, Koc Y, Turan M, Ozturk M (2007) A comparative study of linear and non-linear regression analysis for ammonium exchange by clinoptilolite zeolite. J Hazard Mater 144:432-437

Kim Y-J, Yang H, Yoon S-H, Korai Y, Mochida I, Ku C-H (2003) Anthracite as a candidate for lithium ion battery anode. J Power Sources 113:157-165

Lv L, Sun P, Gu Z, Du H, Pang X, Tao X, Xu R, Xu L (2009) Removal of chloride ion from aqueous solution by $\mathrm{ZnAl}-\mathrm{NO}_{3}$ layered double hydroxides as anion-exchanger. J Hazard Mater 161:1444-1449

Mateus DMR, Vaz MMN, Pinho HJO (2012) Fragmented limestone wastes as a constructed wetland substrate for phosphorus removal. Ecol Eng 41:65-69

Morteau B, Galvez-Cloutier R, Leroueil S (2008) Développement d'une chaîne de traitement pour l'atténuation des contaminants provenant des sels de voiries de l'autoroute Félix-Leclerc: lit filtrant et marais épurateur construit adapté. Raport Technique, Université Laval, Quebec

Okumura M, Kitano Y (1986) Coprecipitation of alkali metal ions with calcium carbonate. Geochim Cosmochim Acta 50:49-58

Pansu M, Gautheyrou J (2006) Handbook of soil analysis. Mineralogical, organic and inorganic methods. Springer, Berlin

Parham H, Saeed S (2013) Simultaneous removal of nitrobenzene, 1,3-dinitrobenzene and 2,4-dichloronitrobenzene from water samples using anthracite as a potential adsorbent. J Environ Chem Eng 1:1117-1123

Prochaska CAA, Zouboulis AII (2006) Removal of phosphates by pilot vertical-flow constructed wetlands using a mixture of sand and dolomite as substrate. Ecol Eng 26:293-303

Rasa K, Peltovuori T, Hartikainen H (2006) Effects of de-icing chemicals sodium chloride and potassium formate on cadmium solubility in a coarse mineral soil. Sci Total Environ 366:819-825

Reddy KR, Xie T, Dastgheibi S (2014) Removal of heavy metals from urban stormwater runoff using different filter materials. J Environ Chem Eng 2:282-292

Rémi S, Ivana D, Guillaume D, Patrice B, Marchetti M (2013) Transfer, exchanges and effects of road deicing salts in a detention pond treating road water. Energy Procedia 36:1296-1299

Santamarina JC, Klein KA, Wang YH, Prencke E (2002) Specific surface: determination and relevance. Can Geotech J 39:233-241

Sdiri A, Higashi T, Jamoussi F, Bouaziz S (2012) Effects of impurities on the removal of heavy metals by natural limestones in aqueous systems. J Environ Manag 93:245-253

Silva AM, Lima RMF, Leão VA (2012) Mine water treatment with limestone for sulfate removal. J Hazard Mater 221-222:45-55

Toprak A, Kopac T (2011) Surface and hydrogen sorption characteristics of various activated carbons developed from rat coal mine (Zonguldak) and anthracite. Chin J Chem Eng 19:931-937

Tromp K, Lima AT, Barendregt A, Verhoeven JTA (2012) Retention of heavy metals and poly-aromatic hydrocarbons from road water in a constructed wetland and the effect of de-icing. J Hazard Mater 203-204:290-298

Vohla C, Kõiv M, Bavor HJ, Chazarenc F, Mander Ü (2011) Filter materials for phosphorus removal from wastewater in treatment wetlands-A review. Ecol Eng 37:70-89

Wang J, Zhang Y, Feng C, Li J, Li G (2009) Adsorption capacity for phosphorus comparison among activated alumina, silica sand and anthracite coal. J Water Resour Prot 04:260-264

Wong T, Breen P, Lloyd S (2000) Water sensitive road design-design options for improving stormwater quality of road runoff. Technical Report 00/1. Cooperative Research Centre for Catchment Hydrology 